\title{
Role of topical insulin therapy in amputation stump
}

Neljo Thomas, Saurabh Gupta, Chirra Likhitha Reddy, Padmalakshmi Bharathi Mohan, Shijina K, Imran Pathan, Nishad K, Daisy Loyola, Daisy Loyola and Ravi Kumar Chittoria*

Department of Plastic Surgery, Jawaharlal Institute of Postgraduate Medical Education and Research (JIPMER), Pondicherry, India-605006

*Corresponding Author: Ravi Kumar Chittoria, Professor, Department of Plastic Surgery, Jawaharlal Institute of Postgraduate Medical Education and Research (JIPMER), Pondicherry, Phone no- 9442285670, India-605006. E-mail: drchittoria@yahoo.com

Received date: June 14, 2020; Accepted date: July 20, 2020; Published date: July 30, 2020

Citation: Thomas N, Gupta S, Likhitha Reddy Ch, Bharathi Mohan P, Shijina K, Imran Pathan, Nishad K, Daisy Loyola, Daisy Loyola and Ravi Kumar Chittoria, Clinical Medical Reviews and Reports.3(1);DOI:10.31579/2690-8794//028.

Copyright: (C) 2020, Ravi Kumar Chittoria: This is an open access article distributed under the Creative Commons Attribution License, which permits unrestricted use, distribution, and reproduction in any medium, provided the original work is properly cited.

\begin{abstract}
Wound healing is a complex process with overlapping steps of haemostasis, the inflammatory and proliferative phases, remodelling. Any problem with the edge of the wound can be detrimental to healing and may cause delay in wound healing. In this article, we share our experience of using topical insulin therapy for wound bed preparation in non-healing ulcer over the amputation stump.
\end{abstract}

Key words: topical insulin, amputation stump

\section{Introduction}

Wound bed preparation is a new concept and is done using the T.I.M.E method. The Edge is a component that involves granulation tissue for better healing. Recently we have come across the application of topical insulin therapy for the management of non-healing ulcer, and we share our experience.

Materials and methods: This study was conducted in the department of Plastic Surgery at tertiary care center after obtaining the departmental ethical committee approval. Informed written consent was taken from patient in study. The details of the patient in study are as follows: 37 year old female with no known co morbidities with h/o road traffic accident 4 months back and underwent right below knee amputation due to vascular injury and degloving injury of the left lower limb for

Which serial debridement was done in cardiothoracic and general surgery department. Now, the patient presented to plastic surgery department with extensive raw area over the left lower limb and non-healing ulcer over the right below knee amputation stump.

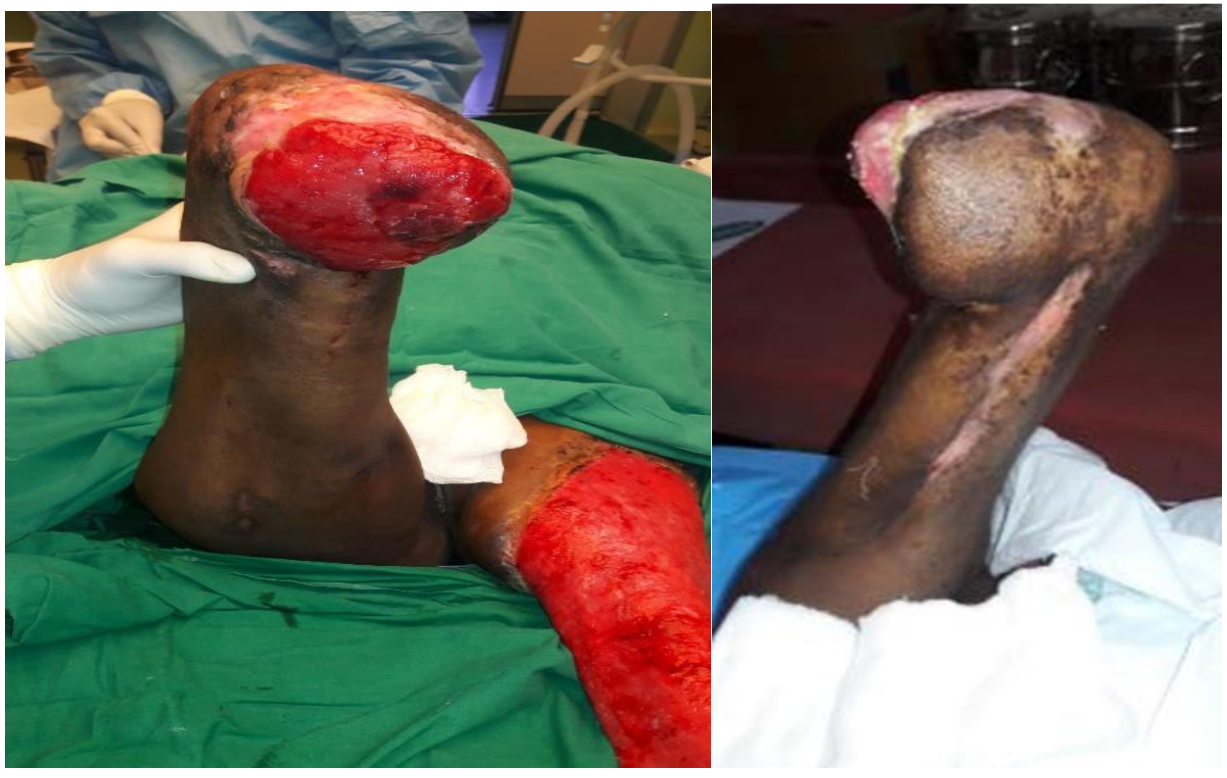

Figure 1: wound over the amputation stump 
The regular dressings and antibiotic changes did not lead to wound healing. Wound bed preparation was done using the patient with topical insulin therapy (figure 2).

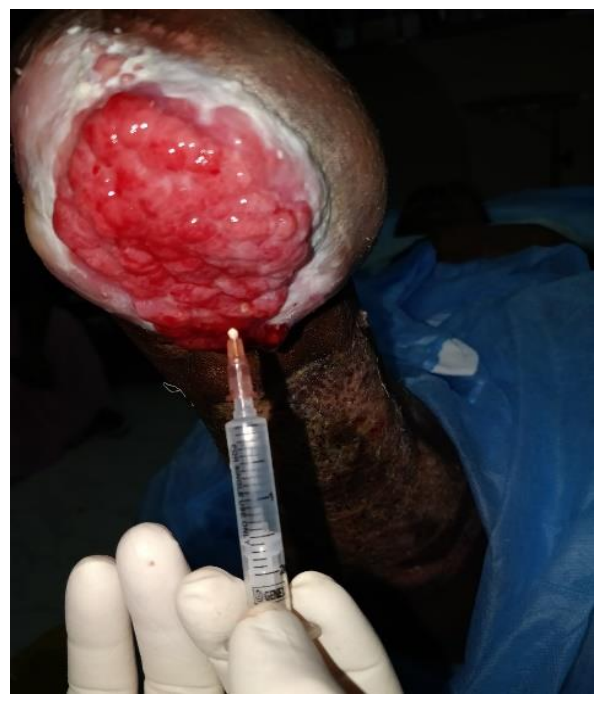

Figure2: topical insulin therapy given to the amputation stump

$0.1 \mathrm{ml}$ of regular insulin was injected or sprayed onto $1 \mathrm{~cm}^{2}$ of the wound when the regular dressing was performed (figure 3). This was repeated once every 3-5 days when the dressing was changed. The wound was reassessed after 2 weeks for evidence of wound healing. The wound showed healing as evidenced by healthy granulation tissue. (figure3)

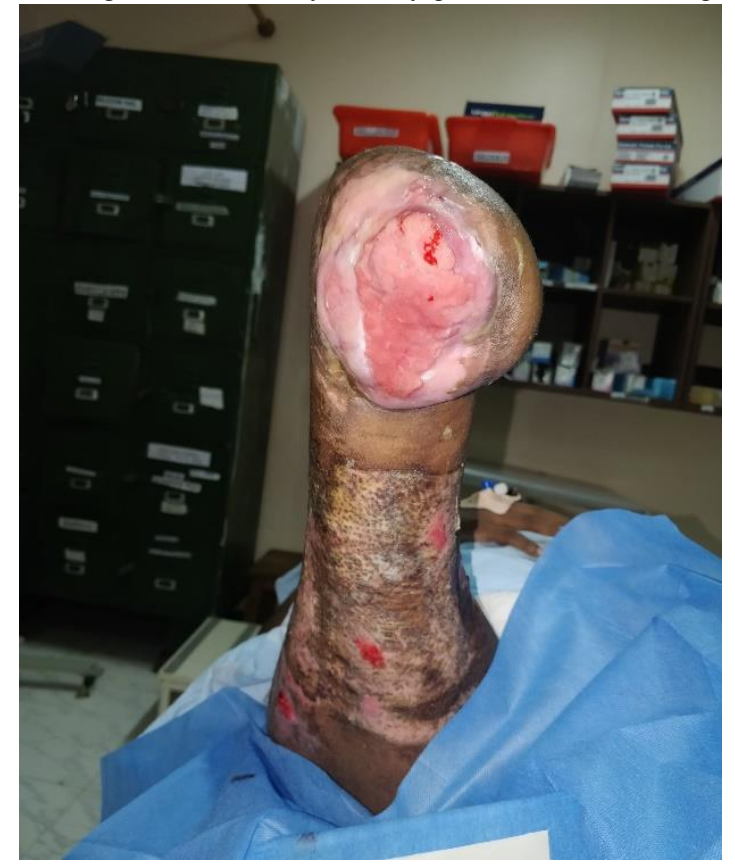

Figure3: healing wound bed

\section{Discussion}

Wound bed preparation was redefined as 'the global management of the wound to accelerate endogenous healing or to facilitate the effectiveness of other therapeutic measures. Wound bed preparation started to be summarized by the acronym T.I.M.E with $\mathrm{T}$ for tissue: non-viable or deficient. I for infection/inflammation, $\mathrm{M}$ for moisture balance. E for epidermis which was later changed to $\mathrm{E}$ for edge. Debridement, control of inflammation and moisture are essential parts of wound bed preparation that may stimulate the edge of the wound to migrate, but if they fail, advanced therapies may be required.

Many therapeutic methods are available to effect the wound healing such as the topical application of insulin, growth factors, negative pressure assisted wound closure, oxidized regenerated cellulose/collagen, hyaluronic acid conjugated with glycidyl methacrylate or gelatin dressings.

Role of topical insulin in wound healing has appeared in literature since $1970 s^{[1]}$. Studies done have found that topical Insulin therapy exerts its effects through the IGF 1 receptor. Insulin is known to stimulate keratinocytes and endothelial proliferation leading to a faster neovascularization as well as formation of granulation tissue ${ }^{[2]}$. Topical insulin application rapidly induces up regulation of the insulin related proteins on wound areas following injury. IRS-1 binds the PI3-kinase, through the multiple tyrosine phosphorylated sites ${ }^{[3,4]}$.

Insulin triggers keratinocyte migration depending on the dose and time in the chronic wounds. Insulin demonstrates its effect by an insulin receptor dependent but EGF/EGF-R non-dependent way. It increases the keratinocyte migration on the PI3K-Akt-Rac1 pathway, cause stimulation of keratinocytes by enabling the production of $\alpha 3$ and LN332 molecules is proved in vitro studies ${ }^{[6,7,8,9]}$. Insulin is a hormone that also has effect on collagen production. Insulin selectively and strongly stimulates the collagen production in dermal fibroblasts ${ }^{[10,11]}$.The cost of insulin ranges from 130-500 INR per vial.

\section{Conclusion}

Topical insulin therapy was found to be useful in management of nonhealing ulcer as it improved the granulation tissue. Long-term clinical observations are needed to determine whether topical insulin can be used for wound bed preparation.

\section{Limitations}

This was done on a single patient and needs large population based study to apply the finding in clinical practice.

\section{Conflict of interest none}

Disclosure none Financial support none

\section{References}

1. Belfield WO, Golinsky S, Compton MD. (1970). The use of insulin in open-wound healing. Vet Med Small Anim Clin; 65(5):455-460.

2. Scimeca CL, Bharara M, Fisher TK, Kimbriel H, Mills JL, Armstrong DG. (2010); Novel use of insulin in continuousinstillation negative pressure wound therapy as "wound chemotherapy.” J Diabetes Sci Technol 4:820-4.

3. Hrynyk M, Neufeld RJ. (2014); Insulin and wound healing. Burns. 40:1433-1446.

4. Takahashi Y, Tobe K, Kadowaki H, Katsumata D, Fukushima Y, et al (1997); Roles of insulin receptor substrate-1 and Shc on insulin-like growth factor I receptor signaling in early passages of cultured human fibroblasts. Endocrinology. 138:741-750.

5. Garza-Garcia A, Patel DS, Gems D, Driscoll PC. (2007); RILM: a web-based resource to aid comparative and functional analysis of the insulin and IGF-1 receptor family. Hum Mutat. 28:660-668. 
6. Schilling JA. (1976); Wound healing. Surg Clin North Am 56:859-74.

7. Coulombe PA. (2003); Wound epithelialization; accelerating the pace of discovery. J Invest Dermatol 121:219-30.

8. Madibally SV, Solomon V, Mitchell RN, et al. (2003); Influence of insulin therapy on burn wound healing in rats. J Surg Res 109:92-100.

9. Benoliel AM, Kahn-Perles B, Imbert J, Verrando P. (1997); Insulin stimulates haptotactic migration of human epidermal keratinocytes through activation of NF-kappa B transcription factor. J Cell Sci 110:2089-97.

10. Chaiken RL, Moses AC, Usher P, Flier JS. (1986); Insulin stimulation of aminoisobutyric acid transport in human skin fibroblasts is mediated through both insulin and type I insulin-like growth factor receptors. J Clinical Endocrinol Metabolism 63: 1181-5.

11. Flier JS, Usher P, Moses AC. (1986); Monoclonal antibody to the type I insulin-like growth factor (IGF-I) receptor blocks IGFI receptor-mediated DNA synthesis. Clarification of the mitogenic mechanisms of IGF-I and insulin in human skin fibroblasts. Proc Natl Acad Sci USA 83: 664-8.

(c) (i)

This work is licensed under Creative

Commons Attribution 4.0 License

To Submit Your Article Click Here: Submit Article

DOI: $10.315792690-8794 / 028$
Ready to submit your research? Choose Auctores and benefit from:

* fast, convenient online submission

* rigorous peer review by experienced research in your field

* rapid publication on acceptance

* authors retain copyrights

* unique DOI for all articles

* immediate, unrestricted online access

At Auctores, research is always in progress.

Learn more www.auctoresonline.org/journals/clinical-medicalreviews-and-reports 